\title{
Rigidez articular
}

\section{Gustavo da Rocha Velloso ${ }^{I}$}

RESUMO - As causas da rigidez articulatória devem ser bem avaliadas quando presentes na história clínica dos pacientes. Fatores intrínsecos e extrínsecos devem ser considerados com cuidado. A qualidade da superfície articulatória, o nivelamento da cartilagem e a fibrose são causas comuns da queixa de rigidez articular. $\mathrm{O}$ aumento do líquido sinovial e a hipertrofia sinovial podem ser fatores importantes na restrição do movimento articular.

Palavras-chave: articulação, fisiologia, movimento.

\section{Articular stiffness}

\begin{abstract}
The causes of articular stiffness must be critically evaluated as a main complain of a patient. Intrinsic and extrisinc factors should be evavulated and investigated.The shape of the articular surface, congruity of cartilage and fibrosis are commom causesof stiffness. Increase of sinovial fluid and sinovial hyperthrophy can produce restriction of joint movement
\end{abstract}

Key words: joint, physiology, moviment.

Todos os pacientes já experimentaram sensação de rigidez articular após atividade esportiva, ao sentar-se em uma cadeira por longo período ou após um trauma. Mas, raramente, o paciente e o seu terapeuta pensaram no que realmente significa a rigidez articular.

O termo rigidez é definido nos dicionários como: "dificuldade de fletir, rigidez, falta de flexibilidade, dificuldade de movimento suave ou movimentação acompanhada de dor". Poderíamos raciocinar sobre o termo rigidez de duas maneiras para facilitar o entendimento da fisiologia da rigidez articular. Em primeiro lugar, imaginemos uma articulação que move com total amplitude de movimento, sem

\footnotetext{
${ }^{1}$ Professor da disciplina de Ortopedia da Faculdade de Ciências da Saúde do Centro Universitário de Brasília-UniCEUB

E-mail: grvelloso@terra.com.br
} 
qualquer obstáculo. A segunda hipótese é a de uma articulação com restrição de movimento em relação à amplitude normal. Em ambas as situações, estruturas anatômicas e forças atuarão em conjunto ou em separado para executar um movimento articular ou serão bloqueadas pelo fenômeno da rigidez.

Este artigo tem por objetivo analisar e discutir causas e sintomas da rigidez articular descrita pelos pacientes após o trauma e contribuir para melhor compreensão de queixa e ou sintomas da rigidez articular. Consideraremos, em primeiro lugar, a perda do movimento articulatório que pode ter como conseqüências: a falta de elasticidade da cápsula articular; o aumento da resistência de fricção da articulação; a alteração da viscosidade do líquido sinovial.

Uma característica das articulações é que, quando existe aumento de volume interno, a elasticidade capsular é recíproca. Contudo, quando há mudança da posição da articulação, a elasticidade é variável, isto explica por que os pacientes buscam posição confortável para a articulação com aumento de volume e conseqüente distensão capsular. Desta forma, a estrutura intrínseca das articulações é um envelope que varia sua elasticidade de acordo com a quantidade de pressão exercida pelos músculos para mover a articulação. É esta a percepção que o paciente tem ao exercer força maior que o normal para mover a articulação e que produz o sentimento de rigidez articular ${ }^{1}$.

O aumento de resistência de fricção dentro da articulação tem relação direta com a qualidade da superfície articular. Superfícies cartilaginosas, lisas permitem, com facilidade, um movimento articular, o mesmo não acontece com as superfícies irregulares. Patologias articulares que aumentem o índice de fricção da cartilagem produzem sensação de rigidez articular. O líquido lubrificante das articulações é o sinovial que tem a propriedade de mudar a viscosidade de acordo com a solicitação mecânica da articulação. O líquido sinovial mais viscoso requer maior força aplicada à articulação para que possa circular e promover o efeito lubrificante. É importante anotar que a fisiologia normal de uma articulação está intimamente ligada à propriocepção que informa e orienta o paciente para eventual mudança de posição articular e a velocidade do movimento, por meio dos sensores existentes na cápsula articular e ligamentos, mas que estão ausentes no tecido sinovial.

Assim, consideremos um conceito mais comum de rigidez, o qual acontece por redução de movimentos de uma articulação. Três causas essenciais devem ser observadas: alteração intra-articular; alteração peri-articular; alterações extraarticulares.

As causas de rigidez intra-articular são: incongruência da superfície, cor-

\footnotetext{
${ }^{1}$ ATTFIELD, 1996.
} 
pos livres articulares, alteração na superfície, fibrose articular e aumento de volume de líquido sinovial. O conceito de fisiologia articular ensina que superfícies que não se encaixam após o colapso do osso subcondral ou a perda da regularidade cartilaginosa por trauma irão gerar incongruência de ambas as superfícies com conseqüente diminuição de movimento.

Os corpos livres intra-articulares são bem reconhecidos como causadores da diminuição dos movimentos ou da rigidez articular. A origem dos corpos livres deve-se, na sua maioria, às pequenas lesões osteocartilaginosas ou à metaplasia cartilaginosa do tecido sinovial. A falta de posição anatômica determinada dos corpos livres durante a amplitude do movimento articular pode ocasionar travamento, instabilidade e sensação de rigidez articular.

A aderência entre duas superfícies articulares resultantes de deposição de fibrina após episódio inflamatório ou de trauma pode reduzir o movimento articular. Estas aderências podem também ocorrer entre o tecido sinovial e a superfície articular. A artrofibrose é um termo pouco utilizado, mas que explica, de forma correta, o estado patológico de uma articulação com aderências. Outra causa da fibrose articular está relacionada com a manipulação cirúrgica de cotovelo, joelho e ombro $^{2}$.

A dinâmica do líquido sinovial é também fator importante relacionado com a rigidez articular, pois o excesso de líquido articular funciona como fator de obstrução não compressivo, limitando o movimento. O derrame ou o aumento de líquido sinovial pode não ser aparente ao exame da articulação, mas o seu volume afeta a função articular.

As causas peri-articulares da rigidez de uma articulação são: a falta de distensão capsular durante as amplitudes do movimento articulatório e o edema dos tecidos peri-articulares associado ou não a processos inflamatórios regionais. A fibrose que pode ocorrer nas vilosidades da cápsula e a que ocorre na superfície intraarticular produzem o mesmo efeito restritivo em uma articulação. Outra causa, a rigidez, pode estar relacionada a um foco distante da articulação. O exemplo são as fraturas dos ossos longos que produzem fibrose nas bainhas musculares com conseqüente aderência muscular ao osso e diminuição da contratibilidade simulando rigidez na articulação próxima à fratura.

O estudo da fisiologia articular é de extrema importância para entendermos, com clareza, a função de cada elemento e as estruturas anatômicas envolvidas no movimento de uma articulação. Assim, a prática comum das atividades desportivas envolve breve período de aquecimento que não deve ser interpretado somente

\footnotetext{
${ }^{2}$ COUGHLIN,1998.
} 
como uma atividade para aumentar a temperatura corporal e a função muscular mas também como mecanismo de ativação de complexo sistema de receptores articulares que favorecem o melhor desempenho do movimento articular.

É sempre importante lembrar que o tratamento dos sintomas dos pacientes requer conhecimento de causa. Diagnósticos errados são acompanhados de tratamentos errados e provocam a insatisfação do paciente. Dessa forma, é útil observar o pensamento lógico baseado no conhecimento anatômico e na fisiologia e considerar as várias causas possíveis da queixa sobre rigidez $\operatorname{articular}^{3}$.

\footnotetext{
${ }^{3}$ NADE, 1997.
}

\section{Referências}

ATTFIELD SF. "Soft tissue balance and proprioception after total knee replacement". In: $J$ Bone \& Joint Surgery 78 -B: 540-5,1996.

COUGHLIN M. Soft tissue afflictions . Philadelphia: J.B Lippincot, 1818, 1998.

NADE, S. “Joint Stiffness”. In: Current Orthopaedics 11: 48-50, 1997 